\title{
Strategic Redirection through Litigation: Forgoing the anti-trafficking framework to address labour abuses experienced by migrant sex workers
}

\author{
Alison Clancey and Frances Mabon
}

\section{Response to the ATR debate proposition 'It is worth undermining the anti-trafficking cause in order to more directly challenge the systems producing everyday abuses within the global economy.'}

Please cite this article as: A Clancey and F Mahon, 'Strategic Redirection through Litigation: Forgoing the anti-trafficking framework to address labour abuses experienced by migrant sex workers', Anti-Trafficking Review, issue 15, 2020, pp. 171-175, https://doi.org/10.14197/atr.2012201512.

SWAN Vancouver (SWAN) promotes the rights of migrant and immigrant (hereinafter im/migrant) sex workers through front-line service provision and systemic advocacy. In 2019, SWAN began to consider a constitutional challenge against Canadian immigration law, which currently prohibits temporary residents and migrant workers from engaging in sex work. This litigation is designed to at least partially counteract the harmful effects of recent anti-trafficking policies. Mounting a constitutional challenge is a difficult exercise for a small organisation like SWAN, but we have decided that it is nonetheless the most

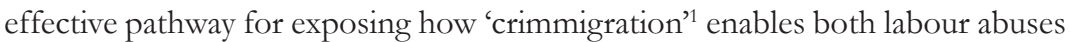
of migrant sex workers and manufactures vulnerability to human trafficking.

Since 2002, SWAN has advocated for im/migrant sex workers, who are primarily from Asia, in the areas of health promotion, legal rights, and criminal justice access. SWAN's front-line work has deeply informed our systemic advocacy with policymakers. For many years now, we have been trying our best to get Canadian law enforcement and multiple levels of government to adopt

1 The intertwining of criminal and immigration law, see: J Stumpf, 'The Crimmigration Crisis: Immigrants, crime, and sovereign power', American University Law Review, vol. 56, issue 2, 2006, pp. 367-419.

This is an open-access article distributed under the terms of the Creative Commons Attribution License (CC-BY). Under the CC-BY license, the public is free to share, adapt, and make commercial use of the work. Users must always give proper attribution to the authors and the Anti-Trafficking Review. 
evidence-based anti-trafficking strategies that address root causes and increase labour protections for $\mathrm{im} /$ migrant sex workers. These efforts have included contributions to numerous human trafficking roundtables, providing input and critical responses to policy briefs and legislation, and attempting to raise awareness of both the design and distribution of anti-trafficking funding. Working with law enforcement, SWAN has trained front-line officers and attempted to inform policy from a sex worker rights perspective. It has also proved necessary to challenge ill-informed anti-trafficking raids which target im/ migrant sex workers under the guise of protection.

None of these efforts have been particularly successful. Attempts to inform anti-trafficking policy and law did not translate into meaningful changes in practices. There is significant overlap between anti-trafficking and prostitution law, and they work together to legislate victimhood, which in turn justifies crude attempts at 'rescue'. Attempts to educate police about the differences between human trafficking and im/migrant sex work were unsuccessful. Police continue to enforce laws based upon a rudimentary understanding of human trafficking hinged on victims, villains, and heroes.

SWAN has increasingly withdrawn from government-sponsored and community-based human trafficking forums and roundtables. We realised there is limited space for perspectives that challenge anti-trafficking rhetoric by centring im/migrant sex workers' voices around migration and labour in a global economy. The human trafficking discourse in Canada is used as a cover to legislate, limit and curtail the activities of sex workers. ${ }^{2}$ It also informs an antisex work crusade, which rehashes misinformation about the sex industry in order to justify ever-increasing anti-trafficking resources. ${ }^{3}$

SWAN realised that working within the anti-trafficking framework was not going to lead to the protection of migrant sex workers' rights. Hence, SWAN's proposed constitutional challenge at least partly stems from a lack of faith in the value of working within existing structures. There is no other recourse SWAN could ethically undertake to advance the labour and migration needs of the women we serve. Moreover, recent changes to immigration policy, which

2 S K H Chu, J Clamen, and T Santini, The Perils of 'Protection': Sex workers' experiences of law enforcement in Ontario, Canadian HIV/AIDS Legal Network, 2019, retrieved 25 June 2020, http://www.aidslaw.ca/site/the-perils-of-protection.

3 See Public Safety Canada, 2018 Human Trafficking Consultations Report, Ottawa, 2019, retrieved 25 June 2020, https:/ / www.publicsafety.gc.ca/cnt/rsrcs/pblctns/2018-hmntrffckng-cnslttns-rprt/2018-hmn-trffckng-cnslttns-rprt-en.pdf; and Standing Committee on Justice and Human Rights, Moving Forward in the Fight Against Human Trafficking in Canada, Ottawa, 2018, https://www.ourcommons.ca/Content/ Committee/421/JUST/Reports/RP10243099/justrp24/justrp24-e.pdf. 
increase labour protections for some migrant workers, continue to exclude migrant sex workers, since they do not hold employer-specific work permits. ${ }^{4}$

The constitutional challenge has been carefully designed to strategically target three specific regulations in the Immigration and Refugee Protection Regulations (IRPR), which make it impossible for temporary residents to provide paid sexual services in Canada. We will argue that these regulations violate the rights of migrant sex workers under sections 7 and 15 of the Canadian Charter of Rights and Freedoms by exposing migrant sex workers to unnecessary harms and discriminating against them on the basis of sex, race, and national or ethnic origin. We will seek to have the three regulations held unconstitutional, and declared to be of no force and effect under section 52, paragraph 1, of the Constitution Act, 1982. This would prevent these particular regulations from being used against migrant sex workers in the future.

SWAN intends to act as a public interest litigant alongside individual plaintiffs who have directly experienced the harms associated with immigration prohibitions on sex work in Canada. Public interest litigants are individuals and organisations who do not directly bear the brunt of the constitutional infringement, but are nevertheless well-placed to bring forward the perspectives of those who risk much in doing so. There is a practical disincentive for migrant sex workers in Canada to sign on as litigants in this case, since it could result in their removal from Canada or victimisation by law enforcement.

The design of immigration law creates barriers to criminal justice responses to the labour abuses experienced by migrant sex workers. Under the current regime, anyone with temporary immigration status in Canada is prohibited from engaging 'with an employer who, on a regular basis, offers striptease, erotic dance, escort services or erotic massages. ${ }^{5}$ Individuals who enter Canada on a work permit, study permit, or visitor's visa have temporary immigration status. If they engage in sex work, they violate immigration regulations. Consequently, immigration law effectively bars migrant sex workers from reporting violence and thus contributes to under-reporting. Any contact with law enforcement, even as victim of a crime, carries the very real risk of detention and deportation.

4 In 2019, the Immigration and Refugee Protection Regulations (s 207.1) allowed Open Work Permits to be issued to temporary foreign workers holding an employer-specific Work Permit, who are experiencing abuse or who are at risk of experiencing abuse in the context of their employment. See Government of Canada, 'Program Delivery Update: Vulnerable workers', 4 June 2019, https:/ / www.canada.ca/en/immigration-refugeescitizenship/corporate/publications-manuals/operational-bulletins-manuals / updates/2019-vulnerable-workers.html.

5 Government of Canada, Immigration and Refugee Protection Regulations, ss. 183(1) and 196.1, last amended 30 April 2020, https://laws-lois.justice.gc.ca/PDF/SOR-2002227.pdf. 
As a consequence, unscrupulous individuals use the threat of detention and deportation to exploit sex workers. Immigration law enables perpetrators of violence to act with impunity, thereby protecting them from prosecution instead of protecting migrant sex workers from labour exploitation. The government's unwillingness to consider how border control and immigration policy contribute to an environment ripe for labour exploitation and trafficking has resulted in an impenetrable policy arena.

Within the anti-trafficking framework, it is impossible for a small community organisation like SWAN to be on a level playing field with powerful stakeholders such as government, law enforcement, and well-funded anti-trafficking organisations. Taking a politically combative stance by way of litigation compels government and other key stakeholders to look beyond awareness campaigns and the prosecution of individual traffickers as primary strategies. By using the legal system, SWAN aims to force a much-needed dialogue about international migration, the global economy, labour protections — or the lack thereof-for migrant workers, and the racialised assumptions about migrant women that led to the creation of the immigration prohibition on sex work and its subsequent enforcement. We also seek to highlight the government's complicity in creating systems that exacerbate systemic vulnerability to human trafficking. It was not possible to place these issues on centre stage within the anti-trafficking framework.

Although the tactical decision to litigate does not guarantee increased labour protections for migrant sex workers, it compels anti-trafficking stakeholders, namely the federal government and police, to re-examine popular yet ineffective strategies to address human trafficking. While risky, SWAN sees no other way to foreground a discussion about who is entitled to criminal justice and labour rights in Canada in the context of migrant sex work.

What we do know is that the status quo is unacceptable. In Canadian society, migrant sex workers exist in a space that does not offer labour protections or rights of any type. Using the legal system to expose how criminal justice and immigration responses structurally render migrant sex workers vulnerable to labour exploitation gives us hope that change is possible. Our strategic redirection through litigation re-instils the hope we had lost during our attempts to use the human trafficking framework as a vehicle for that change. 
Alison Clancey is the Executive Director of SWAN Vancouver. Alison's interests are the production and politicisation of trafficking knowledge, crimmigration, and the policing of sex work. She holds a Master's degree in Social Work from the University of Victoria, Canada. Email: info@swanvancouver.ca

Frances Mahon is the owner and founder of Mahon \& Company, a progressive litigation boutique in Vancouver specialising in criminal law, immigration and refugee law, and constitutional law. She has appeared in courts and tribunals across the country, including the Supreme Court of Canada. Frances is often invited to speak on Charter and human rights issues, and she has provided expert witness testimony to both the Senate and the House of Commons. She is proud to support communities who have historically lacked access to justice, including the LGBTQ2S people, im/migrants, sex workers, prisoners, and many others. Email: frances@mahonlitigation.com 